NOTICE: this is the author's version of a work that was accepted for publication in Minerals Engineering. Changes resulting from the publishing process, such as peer review, editing, corrections, structural formatting, and other quality control mechanisms may not be reflected in this document. Changes may have been made to this work since it was submitted for publication. A definitive version was subsequently published in MINERALS ENGINEERING, [(2013)] DOI:10.1016/j.mineng.2013.07.020

Please cite this article as: Santos, R.M., Bodor, M., Dragomir, P.N., Vraciu, A.G., Vlad, M., Van Gerven, T. (2013). Magnesium chloride as a leaching and aragonite-promoting self-regenerative additive for the mineral carbonation of calcium-rich materials. Minerals Engineering, DOI: 10.1016/j.mineng.2013.07.020.

\title{
Magnesium chloride as a leaching and aragonite-promoting self-regenerative additive for the mineral carbonation of calcium-rich materials
}

\section{Rafael M. Santos ${ }^{\text {a,*, }}$, Marius Bodor ${ }^{\text {a,b }}$, Paul N. Dragomir ${ }^{\text {a,b }}$, Andreea G. Vraciu $^{\text {a,b }}$, Maria Vlad ${ }^{\text {b }}$, Tom Van Gerven ${ }^{\text {a }}$}

${ }^{a}$ Department of Chemical Engineering, KU Leuven, 3001 Leuven, Belgium

${ }^{\mathrm{b}}$ Department of Environmental Engineering and Metallurgical Technological Systems,

Dunarea de Jos University of Galati, 800201 Galaţi, Romania

* Corresponding author. Tel.: +32 16322350.

Email addresses: rafael.santos@ cit.kuleuven.be (R.M. Santos), bodormarius@yahoo.com (M. Bodor), tom.vangerven@cit.kuleuven.be (T. Van Gerven).

\begin{abstract}
Two approaches for the intensification of the mineral carbonation reaction are combined and studied in this work, namely: (i) the calcium leaching and aragonite promoting effects of magnesium chloride $\left(\mathrm{MgCl}_{2}\right)$, and (ii) the passivating layer abrasion effect of sonication. The alkaline materials subjected to leaching and carbonation tests included lime, wollastonite, steel slags, and air pollution control (APC) residue. Batch leaching tests were conducted with varying concentrations of additives to determine extraction efficiency, and with varying solids-to-liquid ratios to determine solubility limitations. Aqueous mineral carbonation tests, with and without the use of ultrasound, were
\end{abstract}


conducted applying varying concentrations of magnesium chloride and varying durations to assess $\mathrm{CO}_{2}$ uptake improvement and characterize the formed carbonate phases. The leaching of calcium from lime with the use of $\mathrm{MgCl}_{2}$ was found to be atomefficient ( $1 \mathrm{~mol} \mathrm{Ca}$ extracted for every mole $\mathrm{Mg}$ added), but the extraction efficiency from slags and APC residue was limited to 26-35\% due to mineralogical and microstructural constraints. The addition of $\mathrm{MgCl}_{2}$ notably improved argon oxygen decarburization (AOD) slag carbonation extent under sonication, where higher additive dosage resulted in higher $\mathrm{CO}_{2}$ uptake. Without ultrasound, however, carbonation extent was reduced with $\mathrm{MgCl}_{2}$ addition. The benefit of $\mathrm{MgCl}_{2}$ under sonication can be linked to the preferential formation of aragonite ( $85 \mathrm{wt} \%$ of formed carbonates), which precipitates on the slag particles in the form of acicular crystals with low packing density, thus becoming more susceptible to the surface erosion effect of sonication, as evidenced by the significantly reduced carbonated slag particle size.

Keywords: magnesium chloride; leaching additive; aragonite polymorph; ultrasound intensification; mineral carbonation.

\section{Introduction}

Mineral carbonation is an attractive route for the storage of $\mathrm{CO}_{2}$ due to the geochemical stability of the formed carbonates, and is also a potentially viable route for the valorisation of alkaline waste or low-value materials, such as industrial slags, ashes and tailings, due to the reduction of basicity, the predominant stabilization of leaching, and the formation of more marketable mineral products (Bobicki et al., 2012; Pan et al., 2012; Sanna et al., 2012; Bodor et al., 2013; Kirchofer et al., 2013). Much work has been done in recent years to identify suitable materials for mineral carbonation, to understand the fundamental mechanisms that control kinetics and conversion, and to develop processing routes that intensify the reaction whilst reducing energy demand (Zevenhoven et al., 2011; Santos and Van Gerven, 2011). Two main mineral carbonation routes have been established: (i) indirect carbonation, wherein the alkalineearth components (mainly $\mathrm{Ca}$ and/or $\mathrm{Mg}$ ) are first extracted from the solids into an aqueous solution, which is then contacted with $\mathrm{CO}_{2}$ for precipitation of the carbonates, 
and (ii) direct carbonation, wherein the solids (dry, wet or in aqueous slurry) are directly reacted with $\mathrm{CO}_{2}$, and thus the carbonate products are formed together with the inert and residual minerals. In either case, the mobility of the alkaline-earth elements from the solids is a major limitation for achieving high conversion rates and $\mathrm{CO}_{2}$ uptake.

To overcome this problem, researchers have turned to finding suitable leaching agents, which ideally should have high extraction efficiency, but at the same time should have less affinity for the alkaline-earth elements than the carbonate ion $\left(\mathrm{CO}_{3}{ }^{2-}\right)$, to allow the precipitation of carbonates upon pH-swing. Acetic acid $\left(\mathrm{CH}_{3} \mathrm{COOH}\right)$ has been successfully applied for the production of precipitated calcium carbonate (PCC) from steel slag (Eloneva et al., 2008), but after extraction it is necessary to add a strong base (e.g. $\mathrm{NaOH}$ ) to neutralize the acid and promote carbonate precipitation; the neutralized acetate can potentially be regenerated into acetic acid, but at a large processing cost. To avoid regeneration, Eloneva et al. (2009) also tested the efficacy of ammonium salts $\left(\mathrm{NH}_{4} \mathrm{Cl}, \mathrm{CH}_{3} \mathrm{COONH}_{4}, \mathrm{NH}_{4} \mathrm{NO}_{3}\right)$ and found positive results with steel converter slag, but the efficiency was poorer for blast furnace and ladle slags; this was attributed to calcium being predominantly bound as silicates in these materials (as opposed to free lime $(\mathrm{CaO})$ in converter slag). The loss of ammonia $\left(\mathrm{NH}_{3}\right)$ in the off-gas also becomes an added concern when using these additives (Eloneva et al., 2011).

In the present work, a novel approach to enhancing calcium mobility is investigated, namely the use of magnesium chloride $\left(\mathrm{MgCl}_{2}\right)$ as a leaching agent. This concept has its roots in a recent study conducted by our group (Santos et al., 2012) on the sonochemical synthesis at low temperatures of pure aragonite precipitates possessing novel crystal morphology (hubbard squash-like). Aragonite is a polymorph of calcium carbonate typically formed at higher temperatures $\left(90-450{ }^{\circ} \mathrm{C}\right.$ ) and in marine environments (Kitano and Hood, 1962; Passe-Coutrin et al., 1995; Santos et al., 2013b). The strategy of using $\mathrm{MgCl}_{2}$ to promote aragonite during mineral carbonation had been described in earlier studies (Ahn et al., 2007; Hu et al., 2008), with the mechanism being tentatively attributed to the binding of $\mathrm{Mg}^{2+}$ to the calcite polymorph crystal surface, thus inhibiting its growth, and to the reduction in supersaturation with respect to $\left[\mathrm{CO}_{3}{ }^{2-}\right]$ as a result of $\mathrm{pH}$ reduction. Santos et al. (2012) found that by combining $\mathrm{MgCl}_{2}$ with ultrasound, it is possible to obtain high purity aragonite at temperatures as low as $24^{\circ} \mathrm{C}$. It was also observed, in agreement with reported findings of Xiang et al. (2006), that $\mathrm{MgCl}_{2}$ also 
acts as a calcium leaching agent, as upon its addition to a slurry of $\mathrm{Ca}(\mathrm{OH})_{2}$, the calcium becomes solubilised, while the magnesium precipitates as $\operatorname{Mg}(\mathrm{OH})_{2}$ (Eq. 1). Subsequently, upon carbonation, the calcium precipitates as $\mathrm{CaCO}_{3}$, while the magnesium returns into solution with the chloride (Eq. 2). Both steps are exothermic, but most of the reaction heat is released in the carbonation step.

$\mathrm{Ca}(\mathrm{OH})_{2(\mathrm{~s})}+\mathrm{MgCl}_{2(\mathrm{aq})}+\mathrm{H}_{2} \mathrm{O}_{(\mathrm{l})} \rightarrow \mathrm{Mg}(\mathrm{OH})_{2(\mathrm{~s})}+\mathrm{CaCl}_{2(\mathrm{aq})}$

$\Delta \mathrm{H}_{\text {Eq. (1) }}^{\circ}=-19.4 \mathrm{~kJ} / \mathrm{mol}$

$\mathrm{CaCl}_{2(\mathrm{aq})}+\mathrm{H}_{2} \mathrm{CO}_{3(\mathrm{aq})}+\mathrm{Mg}(\mathrm{OH})_{2(\mathrm{~s})} \rightarrow \mathrm{CaCO}_{3(\mathrm{~s})}+\mathrm{MgCl}_{2(\mathrm{aq})}+2 \mathrm{H}_{2} \mathrm{O}_{(\mathrm{l})}$

$\Delta \mathrm{H}_{\text {Eq. (2) }}^{\circ}=-160.8 \mathrm{~kJ} / \mathrm{mol}$

These reaction steps are illustrated in Fig. 1 with crystallographic data from Ceulemans (2011). At first, when magnesium chloride is added to a slurry of calcium hydroxide (portlandite), formation of brucite $\left(\mathrm{Mg}(\mathrm{OH})_{2}\right)$ is seen. Once $\mathrm{CO}_{2}$ is introduced into the slurry, carbonic acid reacts with dissolved calcium, forming calcite and aragonite polymorphs of calcium carbonate (the ratio of these depends on other reacting conditions, studied by Santos et al. (2012)). As the reaction progresses, carbonate diffraction peaks become predominant while brucite peaks shrink, indicating solubilisation back into magnesium chloride. If the reaction is halted prior to completion, the product will contain brucite; this is undesirable as it signifies loss of additive and low product purity. When the reaction is completed, only the diffraction patterns of calcium carbonates can be seen, meaning that magnesium chloride has been fully regenerated.

Key to these reaction steps are the greater solubility of $\mathrm{CaCl}_{2}$ over $\mathrm{MgCl}_{2}$, and the lower solubility of $\mathrm{CaCO}_{3}$ over $\mathrm{Mg}$-carbonates (Hu et al., 2008). This mechanism prevents the formation of $\mathrm{Mg}$-carbonates in the product, thus ensuring high $\mathrm{CaCO}_{3}$ product purity and additive regeneration. Concurrent precipitation of $\mathrm{Ca}-$ and $\mathrm{Mg}$ carbonates is also prevented since it would imply the formation of $\mathrm{HCl}$ in solution, unless this was neutralized with, for example, ammonia $\left(\mathrm{NH}_{3}\right)$ (Ferrini et al., 2009). As such, this self-regenerative mechanism also enables the re-utilization of the magnesium chloride-rich solution in further carbonation cycles without the need for purification or 
re-crystallization (Ma et al., 2011; Santos et al., 2012). One constraint of this approach, however, is that it is applicable only to direct carbonation systems, as the leached solids, containing the precipitated $\operatorname{Mg}(\mathrm{OH})_{2}$, cannot be separated from the Ca-rich solution prior to carbonation. Besides leaching of $\mathrm{CaO}, \mathrm{MgCl}_{2}$ also has the potential to leach calcium from siliceous materials, as it is a known contributor to cement and concrete corrosion exposed to saline waters (Kurdowski and Duszak, 1995).

Based on these findings, the present work aims to study the calcium leaching efficiency of $\mathrm{MgCl}_{2}$ for a variety of alkaline materials useful for mineral carbonation, with particular emphasis in accessing the ability of $\mathrm{MgCl}_{2}$ to leach calcium from Casilicate, $\mathrm{Ca}$-ferrite, $\mathrm{Ca}$-sulphate and $\mathrm{Ca}$-aluminate rich materials. Furthermore, this study also investigates the effect of $\mathrm{MgCl}_{2}$ on the mineral carbonation kinetics and conversion. For this purpose, the methodology utilized in another of our studies, reported in Santos et al. (2013a), wherein both mechanical mixing and sonication were utilized for the carbonation of stainless steel slags, is herein adopted. In that study, the application of ultrasound was successfully shown to intensify the mineral carbonation reaction, via the reduction in particle size and the removal of passivating layers (residual silica and mainly calcitic precipitates), thus increasing the specific surface area and exposing the unreacted particle core to the reactive medium.

Here, it is theorized that by combining $\mathrm{MgCl}_{2}$ with ultrasound during the carbonation of silicate-rich and microstructurally heterogeneous alkaline materials, the precipitated carbonate layer will become enriched in aragonite. This effect can have implications on the morphology and on the packing density of carbonate layer, given the different crystal shapes formed by each polymorph: rhombohedral and scalenohedral for calcite, and acicular (needle-like) for aragonite (Santos et al., 2012). In turn, the porosity/permeability of the passivating layer may improve, and it may become more fragile to abrasion/attrition (caused by inter-particles collisions or by sonication cavitations). The ultimate consequence of these effects may be improved carbonation kinetics and/or more extensive carbonation conversion (i.e. greater $\mathrm{CO}_{2}$ uptake); these aspects are investigated in the present work.

\section{Methodology}




\subsection{Alkaline Materials}

A total of six calcium-containing alkaline materials were utilized in leaching and carbonation experiments. Analytical grade lime, with $\mathrm{CaO}$ content of $98.3 \mathrm{wt} \%$, was obtained from Chem-Lab. Milled wollastonite $\left(\mathrm{D}_{50}=57 \mu \mathrm{m}\right)$, with $\mathrm{CaO}$ content of 51.2 wt\%, was obtained from Sibelco Specialty Minerals Europe. Argon Oxygen Decarburization (AOD) and Continuous Casting (CC) slags, with $\mathrm{CaO}$ contents of $56.8 \mathrm{wt} \%$ and $52.1 \mathrm{wt} \%$, respectively, were obtained from a stainless steel producer and sieved to $<500 \mu \mathrm{m}$. Basic Oxygen Furnace (BOF) slag, with $\mathrm{CaO}$ content of $49.0 \mathrm{wt} \%$, was obtained from a steel producer and milled to $<80 \mu \mathrm{m}$. Municipal solid waste incineration (MSWI) air pollution control (APC) residue, with $\mathrm{CaO}$ content of $49.8 \mathrm{wt} \%$, was obtained from an incinerator operator and used as received. The complete chemical and mineralogical compositions of the alkaline materials are presented in Tables 1 and 2, respectively.

\subsection{Leaching Tests}

Leaching tests were performed in sealed polyethylene bottles by mixing one gram of alkaline solids, ultrapure water, and the desired amount of leaching agent, to a total aqueous volume of $100 \mathrm{ml}$, and shaking on a vibration table (Gerhardt Laboshake) at $160 \mathrm{rpm}$ and $25^{\circ} \mathrm{C}$ for 24 hours. Selected experiments were also conducted with varying solids loading (up to $25 \mathrm{~g} / 100 \mathrm{ml}$ ) and leaching duration (30 $\mathrm{min}$ to $48 \mathrm{hrs}$ ) to study the effect of these parameters. At leaching completion, the slurries were filtered with $0.45 \mu \mathrm{m}$ membrane filter, and the solutions were analyzed for dissolved calcium and magnesium contents.

The following reagents were used as leaching agents in this study: magnesium chloride hexahydrate $\left(\mathrm{MgCl}_{2} \cdot 6 \mathrm{H}_{2} \mathrm{O}, 99 \mathrm{wt} \%\right.$, Chem-Lab), hereafter referred to as $\mathrm{MCH}$, sodium chloride $(\mathrm{NaCl}, 99.8 \mathrm{wt} \%$, Chem-Lab), and hydrochloric acid ( $\mathrm{HCl}, 37 \mathrm{wt} \%$, Chem-Lab; diluted to $1 \mathrm{~N}$ prior to use). The different additives were added on the basis of equivalent moles of chloride (namely 2.0, 3.9, 7.9, 15.7 and $31.5 \mathrm{mmol} / 100 \mathrm{ml}$ ) to facilitate comparison of the results. 


\subsection{Carbonation Tests}

Slurry carbonation experiments were conducted using a laboratory glass beaker with a volume of two litres and diameter of approximately $14 \mathrm{~cm}$. The slurry suspension was mixed solely by a mechanical stirrer (Heidolph type RZ-R1) with straight blade impeller at $340 \mathrm{rpm}$ for stirred experiments, or in combination with an ultrasound horn during sonication experiments. The ultrasound horn consisted of a Hielscher UP200S processor, which operates at $24 \mathrm{kHz}$ frequency and delivers $200 \mathrm{~W}$ gross power, coupled to an S14 sonotrode, which has a tip diameter of $14 \mathrm{~mm}$, maximal amplitude of $125 \mu \mathrm{m}$, and an acoustic power density of $105 \mathrm{~W} / \mathrm{cm}^{2}$. The horn was operated at maximum power (net delivery $\sim 170 \mathrm{~W}$ ) and $60 \%$ amplitude (according to optimal conditions found by Santos et al. (2012)). A PT100 temperature sensor was used to monitor solution temperature.

Carbonation experiments were performed with $10 \mathrm{~g}$ AOD slag in one litre of ultrapure water, which reached a height of $7.5 \mathrm{~cm}$; for sonication experiments the probe tip was immersed $3.5 \mathrm{~cm}$ from the beaker bottom, placed parallel to the stirrer shaft but slightly off-centred due to space constraint. For experiments with $\mathrm{MCH}$ addition, the desired amount $(2.05,4.1,8.3$ or $16.6 \mathrm{~g})$ was added prior to slag addition to allow for complete dissolution. Temperature was controlled by use of a hot plate (IKAMAG RCT) for heating (in the case of stirred experiments) and water bath for cooling (in the case of sonicated experiments, since ultrasound produces heat, which must be dissipated to maintain a constant temperature). A temperature of $50{ }^{\circ} \mathrm{C}$ was maintained during carbonation experiments. Carbon dioxide addition commenced once the target temperature was reached, delivered to the solution by bubbling from a compressed gas cylinder ( $\geq 99.5 \% \mathrm{CO}_{2}$ purity), with flow controlled at $0.72 \mathrm{NL} / \mathrm{min}$ by a Brooks Shorate rotameter. Carbonation duration varied from 30 to $240 \mathrm{~min}$, after which the slurry was filtered (Whatman No. 2), and the recovered solids were dried at $105{ }^{\circ} \mathrm{C}$ overnight.

\subsection{Analytical Methods}


Chemical composition of solid samples was determined by X-ray Fluorescence (XRF, Panalytical PW2400). Mineralogical composition was determined by X-Ray Diffraction (XRD), performed on a Philips PW1830 equipped with a graphite monochromator and a gas proportional detector, using $\mathrm{Cu} \mathrm{K} \alpha$ radiation at $30 \mathrm{~mA}$ and $45 \mathrm{kV}$, step size of $0.03^{\circ} 2 \theta$ and counting time of $2 \mathrm{~s}$ per step, over $10-65^{\circ} 2 \theta$ range. Mineral identification was done in Diffrac-Plus EVA (Bruker) and mineral quantification (QXRD) was performed by Rietveld refinement technique using Topas Academic v4.1 (Coelho Software). The volume-based particle size distributions and mean particle diameters were determined by wet Laser Diffraction (LD, Malvern Mastersizer). The powder morphology was observed by Scanning Electron Microscopy (SEM, Philips XL30). The $\mathrm{CO}_{2}$ uptake of carbonated materials was quantified by Thermal Gravimetric Analysis (TGA, Netzsch STA 409), operated from 25 to $900{ }^{\circ} \mathrm{C}$ under nitrogen flow at a heating rate of $15{ }^{\circ} \mathrm{C} / \mathrm{min}$. The amount of $\mathrm{CO}_{2}$ released was quantified by the weight loss between $500-800{ }^{\circ} \mathrm{C}$, which is attributable to $\mathrm{CaCO}_{3}$ decomposition. Determination of aqueous elemental concentrations was performed by Inductively Coupled Plasma Mass Spectroscopy (ICP-MS, Thermo Electron X Series) on samples diluted in $0.3 \mathrm{M}$ nitric acid solution.

\section{Results and Discussion}

\subsection{Leaching Results}

\subsubsection{Aqueous phase analyses}

The results of batch leaching tests, utilizing six different alkaline materials and three different leaching agents, are presented in Fig. 2. Leaching results are expressed as percentage fraction of calcium extracted from the alkaline materials, based on the XRF determined $\mathrm{CaO}$ composition of the solids. To facilitate comparison of the results, the amounts of leaching agents are normalized on the basis of moles of added chloride, the chemical species that combines with calcium to form soluble $\mathrm{CaCl}_{2}$.

The results indicate that sodium chloride is a generally ineffective calcium leaching agent, as its addition results in only incremental improvement beyond the innate solubility of calcium from the differing materials. Jo et al. (2012) similarly obtained 
only $1 \%$ improvement in calcium leaching extent (from 4.6 to $5.6 \%$ ) from Ordinary Portland Cement (OPC) in $0.5 \mathrm{M} \mathrm{NaCl}$. This confirms that calcium leaching is driven by the greater solubility of calcium hydroxide over the hydroxide of the additive; that is, as $\mathrm{NaOH}$ is more soluble than $\mathrm{Ca}(\mathrm{OH})_{2}$, the addition of $\mathrm{NaCl}$ does not result in significant calcium leaching.

The most effective leaching agent is $\mathrm{HCl}$, unsurprisingly as this is the most acidic additive, enabling 73-94\% Ca extraction efficiency from the different solids at the highest tested dosage. The strong affinity of hydronium ions $\left(\mathrm{H}_{3} \mathrm{O}^{+}\right)$for hydroxyl ions $\left(\mathrm{OH}^{-}\right)$, leading to the neutralization reaction, results in the formation of highly soluble chlorides of the alkali components of the solid substrates. This effect, however, means that $\mathrm{HCl}$ is not selective for calcium, being able to solubilise other major components of the alkaline materials, especially Mg (74-100\% extraction from three slags and APC residue at highest dosage).

Magnesium chloride hexahydrate $(\mathrm{MCH})$ proves to be even more efficient than $\mathrm{HCl}$ for calcium leaching from $\mathrm{CaO}$ at every dosage tested, up to a maximum leaching of $100 \%$. For the three slags and the APC residue, MCH performed moderately well, achieving 26-35\% calcium leaching. For wollastonite, however, the extraction efficiency of $\mathrm{MCH}$ was essentially nil. This suggests that mineralogy is the most likely reason for the lower calcium extraction efficiency of $\mathrm{MCH}$ versus $\mathrm{HCl}$, given that the slags and APC residue are predominantly composed of silicates, ferrites, sulphates and aluminates, most of which likely require lower $\mathrm{pH}$ to hydrolyze compared to lime. In particular, the monocalcium silicate $\left(\mathrm{CaSiO}_{3}\right)$ that makes up wollastonite (Table 2) appears to be substantially less reactive with respect to $\mathrm{MCH}$ than the complex silicates that make up the slags (e.g. $\beta$ - and $\gamma$-dicalcium silicates, bredigite, merwinite...). Analogously, it is known that wollastonite requires much more aggressive conditions (i.e. higher $\mathrm{T}$ and $\mathrm{P}$ ) to be susceptible to aqueous mineral carbonation than steel slags (Huijgen et al., 2006).

Fig. 3a presents the dissolution of calcium from $\mathrm{CaO}$ on a molar basis, as a function of moles MCH added. This plot enables the determination of how atom-efficiently $\mathrm{MCH}$ extracts calcium. It can be seen that the amount of solubilised calcium (denoted $\mathrm{Ca}(\mathrm{sol})$ in the graph) is linearly proportional to the amount of $\mathrm{MCH}$ added, and is constantly greater than the 1:1 relationship. Upon further inspection, it is found that the 
difference between the experimental and 1:1 lines is equal to the solubility of $\mathrm{CaO}$ in pure water (first data point). Hence, by deducting this value from the experimental data points, the new line (denoted $\mathrm{Ca}(+\mathrm{sol})$, to refer to the added $\mathrm{Ca}$ solubilisation obtained by additive use) lies precisely on the 1:1 line. This means that $\mathrm{MCH}$ atom-efficiently leaches calcium from $\mathrm{CaO}$ (i.e. $1 \mathrm{mmol} \mathrm{Ca}$ leached for every millimole $\mathrm{Mg}$ added) and that the innate solubility of $\mathrm{Ca}(\mathrm{OH})_{2}$ (from $\mathrm{CaO}$ hydration) is unaffected by the addition of $\mathrm{MCH}$.

On Fig. $3 b$ the molar solubilisation of calcium from the other five alkaline materials as a function of $\mathrm{MCH}$ addition is presented. It is noted that, with the exception of the unresponsive wollastonite, calcium leaching at first increases proportionally to $\mathrm{MCH}$ addition, but eventually deviates from the slope of the 1:1 line, finally stabilizing at comparable levels $(2.4-3.2 \mathrm{mmol} / 100 \mathrm{ml})$. Incomplete leaching can occur due to the exhaustion of minerals susceptible to leaching by $\mathrm{MCH}$, but can also be caused by the formation of a Ca-depleted silica-rich layer (Daval et al., 2009) or a layer of deposited precipitates (namely brucite $\left(\mathrm{Mg}(\mathrm{OH})_{2}\right)$ ) that surrounds the unreacted material present in the particle core (Kurdowski et al., 2004), possibly reducing permeability and/or increasing diffusion length, and thus limiting the extraction extent. However, brucite deposition might not be the cause, as it crystallizes into loosely packed fibrous structures (Ceulemans, 2011), and in an analogous study (Sinadinović et al., 1997), where $\mathrm{CaCl}_{2}$ was used for leaching $\mathrm{Pb}$ from $\mathrm{PbSO}_{4}$, resulting in the precipitation of a layer of insoluble $\mathrm{CaSO}_{4}$, this layer was found to be porous and to not appreciably impede leaching. It is also apparent from Fig. $3 \mathrm{~b}$ that leaching from BOF slag and APC residue at zero $\mathrm{MCH}$ addition (i.e. in water only) is greater than from the stainless steel slags, which is attributable to greater contents of lime (for BOF slag), portlandite $\left(\mathrm{Ca}(\mathrm{OH})_{2}\right)$ and calcium chloride hydroxide $(\mathrm{Ca}(\mathrm{OH}) \mathrm{Cl})$ (for APC residue) in their mineral composition (Table 2).

The atom-efficiency of MCH used as a calcium leaching agent is further elucidated in Fig. 3c, where the percentage of added $\mathrm{Mg}$ remaining in solution after leaching $(\mathrm{Mg}, \mathrm{sol})$ is plotted versus the amount of added MCH. It should be restated that the calcium leaching mechanism involves the precipitation of brucite $\left(\mathrm{Mg}(\mathrm{OH})_{2}\right)$, and thus effective use of $\mathrm{MCH}$ should result in disappearance of $\mathrm{Mg}$ from solution. This is indeed the case for $\mathrm{CaO}$; Fig. $3 \mathrm{c}$ shows that dissolved $\mathrm{Mg}$ remains essentially nil up to 
$16 \mathrm{mmol} / 100 \mathrm{ml}$ (sufficient to leach $0.9 \mathrm{~g} \mathrm{CaO}$ ). The opposite occurs for wollastonite, with essentially all added $\mathrm{Mg}$ remaining in solution due to the low reactivity of the material. In the case of the steel slags, the amount of solubilised $\mathrm{Mg}$ is nil for low $\mathrm{MCH}$ additions, indicating high leaching efficiency ( $\geq 99 \%$ ), but eventually increases as the amount of extractable calcium (i.e. calcium amiable to $\mathrm{MCH}$ leaching) in the slags decreases. In contrast, in the case of APC residue, the leaching efficiency (100\%$\% \mathrm{Mg}, \mathrm{sol})$ of $\mathrm{MCH}$ is consistently lower, even for the smallest amount of $\mathrm{MCH}$ addition (45\%). This can be explained by the fact that much of the calcium leaching at this level is due to the inherent solubility of the residue, and so only part of the magnesium added participates in the leaching/precipitation extraction mechanism.

To test if solubility limitation may also limit calcium extractability, besides the other possible aforementioned mineralogical mechanisms, and to assess the scalability of $\mathrm{MCH}-e n h a n c e d$ leaching in view of mineral carbonation processes, experiments were performed using CC slag with increasing solids concentrations (from 1.0 to $25.0 \mathrm{~g} / 100 \mathrm{ml})$, at fixed $\mathrm{MCH}$ to slag ratio of $0.8: 1$, and 24 hours duration. These results are presented in the first set of data of Fig. 4, where the amount of soluble calcium is normalized on the basis of millimoles leached per gram solids. As can be seen, the normalized concentration of calcium remains essentially constant (within an experimental variability of $\pm 3 \%$ ) up to $10 \mathrm{~g} / 100 \mathrm{ml}$, and slightly decreases at $25 \mathrm{~g} / 100 \mathrm{ml}$, possibly as a result of poor mixing at this high solids loading.

Another experimental variation presented in the second set of data of Fig. 4, also aiming to test extraction limitations, consisted in sequentially leaching CC slag with MCH three times, for 24 hours each batch, at a fixed MCH to slag loading ratio of 4.0:5 (g/100ml units). Calcium leaching from the second and third extractions was found to be negligible. Based on these two sets of experiments, it can be said that $\mathrm{MCH}$ enhanced calcium leaching does not reach a limiting capacity in the operating range tested. Thus mineralogical mechanisms are most likely responsible for limiting $\mathrm{MCH}-$ enhanced calcium extraction to lower levels than those achieved with $\mathrm{HCl}$ ( $26 \%$ versus $86 \%$ in the case of CC slag (Fig. 2)).

Lastly, the effect of leaching duration was also assessed using a fixed $\mathrm{MCH}$ to slag loading ratio of $0.8: 1$; results are presented in the third set of data of Fig. 4 . It is found that $\mathrm{MCH}$ leaching is time-dependent, but that in the first 30 minutes approximately 
half of the leaching that occurs after 48 hours takes place. This is satisfactory, since carbonation reactions of $\mathrm{Ca}$-bearing materials usually last for tens of minutes to a few hours, and thus the leaching and carbonation reactions can potentially occur simultaneously.

\subsubsection{Solid phase analyses}

More insight on the mineralogical mechanisms of $\mathrm{MCH}$-assisted Ca-leaching was gained by analyzing leached solids by QXRD and comparing the mineralogical changes to the pre-leaching materials. Results are presented in Fig. 5, which includes superimposed pre- and post-leaching diffractograms and quantitative comparative data. These experiments were conducted with $\mathrm{MCH}$ to solids loading ratio of 4.0:5 to produce sufficient leached materials for analysis.

In the case of $\mathrm{CaO}$, Fig. 5a shows that, predictably, lime is at first transformed to portlandite $\left(\mathrm{Ca}(\mathrm{OH})_{2}\right)$. The calcium leaching from this material is reflected by the significant amount of brucite $\left(\mathrm{Mg}(\mathrm{OH})_{2}\right)$ formation (21 wt\% in the leached solids). Evidently, since the amount of $\mathrm{MCH}$ in this experiment was not sufficient to fully leach all the calcium ( $18 \mathrm{~g} \mathrm{MCH}$ would have been required for complete leaching of $5 \mathrm{~g}$ $\mathrm{CaO})$, the leached solids still contain a substantial amount of portlandite.

In the case of wollastonite (Fig. 5b), the diffractograms of the pre- and post-leaching materials are virtually identical, in agreement with its negligible response to $\mathrm{MCH}$ leaching. The APC residue underwent significant mineralogical changes (Fig. 5c). In particular, portlandite and calcium chloride hydroxide were almost completely dissolved (87-95\%), while significant formation of brucite was detected (38 wt \%). The increase of anhydrite $\left(\mathrm{CaSO}_{4}\right)$ concentration is most likely a result of mass enrichment, since a substantial proportion of the material dissolved into the $\mathrm{MCH}$ solution (due to $\mathrm{MCH}-$ induced leaching as well as innate dissolution of soluble salts inherently present, including halite, sylvite and tachyhydrite (Table 2)).

The stainless steel slags underwent less significant changes in mineralogy (Figs. 5d and 5e), with some reduction (11-21\%) in the amounts of $\gamma$-dicalcium silicate and bredigite (the latter only for AOD slag). It is possible that other alkali phases partially solubilise, but if they do so in similar proportions (i.e. congruently), it becomes difficult to gauge such changes by XRD analysis. Also, only modest deposition of brucite was 
detected in CC slag (3 $\mathrm{wt} \%$ ), possibly as the complex diffraction patterns of the slags can mask small changes in composition. Finally, the simple calcium minerals from BOF slag (lime and portlandite) were, as could be expected, significantly solubilised in the presence of $\mathrm{MCH}$ (Fig. 5f). This resulted in appreciable precipitation of brucite $(16 \mathrm{wt} \%)$.

\subsection{Carbonation Results}

In view of the positive effect of magnesium chloride in enhancing the leaching of calcium from alkaline materials, experiments were conducted to test if the use of $\mathrm{MCH}$ as an additive to aqueous mineral carbonation improves carbonation kinetics or extends carbonation conversion, and for that matter $\mathrm{CO}_{2}$ uptake. An additional hypothesis to be tested was if the promotion of the aragonite polymorph of calcium carbonate, known to occur at moderate reaction temperatures in the presence of dissolved $\mathrm{Mg}$ coupled to sonication (Santos et al., 2012), could also affect the kinetics, conversion and uptake. As such, a series of experiments was conducted emulating the carbonation conditions utilized in Santos et al. (2013a), wherein the effect of ultrasound for the intensification of the carbonation of AOD and CC slags was tested and confirmed.

In the current study, AOD slag was selected as the carbonating material. This slag was chosen as, compared to CC slag and based on our prior works (Santos et al., 2013a and b), it stands to benefit most from improved conversion. Four experimental variations were performed: (i) mixer-only without $\mathrm{MCH}$; (ii) mixer-only with $\mathrm{MCH}$; (iii) combined mixer/ultrasound without $\mathrm{MCH}$; and (iv) combined mixer/ultrasound with $\mathrm{MCH}$. The other experimental parameters varied were reaction time (30, 120 and 240 minutes) and, for experiments with $\mathrm{MCH}$ addition, amount of $\mathrm{MCH}$ added (2.05, $4.1,8.3$ and $16.6 \mathrm{~g} / \mathrm{L})$.

\subsection{1 $\mathrm{CO}_{2}$ uptake analysis}

The results of carbonation tests, expressed in the form of $\mathrm{CO}_{2}$ uptake determined by TGA, are presented in Figs. 6a (mixer-only) and $6 \mathrm{~b}$ (combined mixer/ultrasound). The maximal theoretical $\mathrm{CO}_{2}$ uptake capacity of AOD slag, based on its $\mathrm{CaO}$ composition, is $0.446 \mathrm{~g}, \mathrm{CO}_{2} / \mathrm{g}$,slag. The $\mathrm{CO}_{2}$ uptake was significantly enhanced with the use of 
ultrasound, for both the cases with and without $\mathrm{MCH}$ (increasing from a range of 0.10 0.14 to the range of $0.19-0.27 \mathrm{~g}, \mathrm{CO}_{2} / \mathrm{g}$,slag after 240 minutes). This finding agrees with our previous work (Santos et al. 2013a), and can be attributed to the reduction in particle size and removal of passivating layers (Ca-depleted silica-rich layer, and deposited carbonates) caused by sonication (see Fig. 7b; further discussion follows in Section 3.2.2).

The addition of $\mathrm{MCH}$ notably improved carbonation extent when using ultrasound (Fig. 6b), where higher $\mathrm{MCH}$ dosage resulted in higher $\mathrm{CO}_{2}$ uptake for each reaction duration used. For the case of mixer-only, however, it is seen that only for the lowest MCH dosage the $\mathrm{CO}_{2}$ uptake is slightly enhanced (Fig. 6a); at higher MCH dosages the carbonation extent is reduced, for each of the reaction durations used. It is also found that the $\mathrm{CO}_{2}$ uptake of mixer/ultrasound $+\mathrm{MCH}$ experiments significantly surpasses those of mixer-only $+\mathrm{MCH}$ at longer reaction times only (120 and $240 \mathrm{~min}$ ), while at 30 min the $\mathrm{CO}_{2}$ uptakes are comparable.

These observations suggest that the carbonation enhancement effect of $\mathrm{MCH}$ is not due to calcium leaching enhancement; in fact, it appears that $\mathrm{MCH}$ leaching delays the carbonation kinetics (this was also experienced with $\mathrm{Ca}(\mathrm{OH})_{2}$ carbonation experiments conducted by Santos et al. (2012)). Mignardi et al. (2011) suggest that $\mathrm{MgCl}_{2}$ lowers the degree of $\mathrm{CO}_{2}$ degassing, thus regulating the availability of carbonic ions in solutions. Verification by geochemical modelling (Table 3) confirms that $\mathrm{MCH}$ additions to calcite-saturated solution enhances the dissociation of carbonic acid $\left(\mathrm{H}_{2} \mathrm{CO}_{3(\mathrm{aq})}\right)$. These same simulations also show that the salting-out effect, where the solubility of $\mathrm{CO}_{2}$ decreases as a function of electrolyte concentration (Yasunishi and Yoshida, 1979), is prevented in a calcite-saturated system. Kinetic effects, however, are not captured in these equilibrium simulations, and could play a role in the slowing of $\mathrm{MCH}$-mediated carbonation. It thus appears that mineralogical and microstructural effects are most likely responsible for the carbonation improvement achieved in the sonicated experiments, as discussed next.

\subsubsection{Mineralogical and morphological analyses}

The mineralogical composition of the three main carbonate products formed in the carbonated slags, determined by QXRD, is presented in Fig. 7a. The values for 
experiments performed with different $\mathrm{MCH}$ dosages have been averaged for ease of comparison, as the quantification variability was relatively low ( $\pm 10 \mathrm{wt} \%)$. It is apparent that in experiments without $\mathrm{MCH}$ addition, calcite was the predominant carbonate phase formed. The addition of $\mathrm{MCH}$ to mixer-only experiments led to the formation of significant quantities of magnesian calcite (nominal chemical formula $\mathrm{Ca}_{1}$. ${ }_{x} \mathrm{Mg}_{x} \mathrm{CO}_{3}$, where $x$ is typically $0-0.15$ (Kitano et al., 1979)), although aragonite was predominant at $120 \mathrm{~min}$. It is possible that small quantities of $\mathrm{Mg}$ from $\mathrm{MCH}$ additions became incorporated in the forming carbonates in these experiments, as was observed by Kim et al. (2006). The morphologies of the precipitated layers of these two carbonate products around the slag particles are very distinct: magnesian calcite crystals form into compact agglomerates (Figs. 8b and 8e) while aragonitic acicular (needle-like) crystals effloresce into less microstructurally packed formations (Figs. 8a and 8d).

In the case of sonicated experiments with $\mathrm{MCH}$, the preferential formation of aragonite is clearly evidenced in Fig. 7a; however, due to extensive attrition of the particles caused by sonication, the crystal morphology is not clearly discernible in Figs. 8c and 8f. Santos et al. (2012) attributed the formation of aragonite under sonication to two mechanisms: (i) imploding cavities generate localized regions of high temperature that can lead to the nucleation of aragonite seeds, given aragonite formation is promoted at higher temperatures; and (ii) the nucleation rate may be enhanced by sonication, thus maintaining stochastically preferable aragonite formation over calcite even at low crystal growth bulk temperatures. It should also be noted that insignificant amounts of brucite were detected in the carbonated slags ( $<0.5 \mathrm{wt} \%)$, suggesting that the passivation of the particles by brucite deposition was not the cause of the detrimental effect of $\mathrm{MCH}$ on the $\mathrm{CO}_{2}$ uptake of mixer-only experiments.

The formation of aragonite can be tied to the further reduction in particle size for experiments combining ultrasound with $\mathrm{MCH}$ (Fig. 7b). The use of ultrasound, without $\mathrm{MCH}$, reduces the volume moment mean diameter $(\mathrm{D}[4,3])$ of the carbonated slag from the range of $61-78 \mu \mathrm{m}$ to a range of $44-48 \mu \mathrm{m}$, and the surface area moment mean diameter $(\mathrm{D}[3,2])$ from $6.0-8.3 \mu \mathrm{m}$ to $4.2-4.8 \mu \mathrm{m}$. The addition of $\mathrm{MCH}$ to sonicated tests further reduces the $\mathrm{D}[4,3]$ and $\mathrm{D}[3,2]$ to as low as 26 and $1.6 \mu \mathrm{m}$, respectively, after 240 min reaction time (particle morphology shown in Figs. 8c and 8f). 
These reductions are significant, and can be explained by two mechanisms (Santos et al., 2013a): (i) the erosion of large particles is indicated primarily by the $\mathrm{D}[4,3]$ value (as it is sensitive to particle volume changes), and (ii) the formation of micron- to submicron sized fragments is reflected on the $\mathrm{D}[3,2]$ value (which is sensitive to the formation of surface area). It thus appears that aragonitic crystals, due to their acicular morphology and arrangement, are more easily cleaved off the surface of the carbonated particles due to sonication, either through the induction of cavitation shock waves and micro-jetting on the particle surface (as observed by Shu et al. (2012)), or through enhanced inter-particle collisions (as recorded by Prozorov et al. (2004)).

\section{Conclusions}

This work studied the utilization of magnesium chloride $\left(\mathrm{MgCl}_{2}\right)$ as an additive for the improvement of the mineral carbonation of alkaline materials. The objective was to leverage two aspects of $\mathrm{MgCl}_{2}$ to improve the carbonation reaction kinetics and extent: (i) its ability to enhance the leaching of calcium, via a reversible precipitation/solubilisation reaction mechanism, and (ii) its ability to promote (at suitable temperatures or in the presence of sonication) the preferential crystallization of the acicular (needle-like) aragonite polymorph of calcium carbonate $\left(\mathrm{CaCO}_{3}\right)$.

Leaching of lime $(\mathrm{CaO})$ by $\mathrm{MgCl}_{2}$ was found to be atom-efficient; that is, one mole of $\mathrm{Ca}$ is extracted for every mole of $\mathrm{Mg}$ added. For the waste-derived materials (slags and APC residue), however, the efficiency at the highest tested dosage $(0.316 \mathrm{M}$ chloride basis) reduced to levels around 26-35\%, significantly lower than that with $\mathrm{HCl}(73-94 \%)$, but much superior to that of $\mathrm{NaCl}(1-28 \%)$. This leaching limitation of $\mathrm{MgCl}_{2}$ can be linked to the mineralogy of the waste materials, which are predominantly made up to silicates, ferrites, sulphates and aluminates. This effect was particularly evident from the very poor calcium leaching performance from wollastonite $\left(\mathrm{CaSiO}_{3}\right)$. Conversely, the greater proportion of simple calcium minerals (e.g. lime, portlandite and calcium chloride hydroxide) in BOF slag and APC residue aided in the dissolution of calcium from these materials, as verified by X-ray diffraction. In addition, the formation of a Ca-depleted silica-rich layer surrounding the Ca-rich particle core can increase the diffusion length and contribute to the leaching limitation. Solubility limits, 
on the other hand, were not reached in the concentration range tested, and leaching kinetics were found to be sufficiently fast, thereby conforming to typical conditions of aqueous mineral carbonation. These results suggest that $\mathrm{MgCl}_{2}$ has the potential to contribute to the intensification of the mineral carbonation reaction.

The effect of $\mathrm{MgCl}_{2}$ on the mineral carbonation of AOD stainless steel slag was tested in both mechanically mixed and sonicated reaction systems. The addition of $\mathrm{MgCl}_{2}$ to mixer-only experiments resulted in reduced carbonation conversion at every reaction duration tested, indicating that it slows the reaction kinetics, proportionally to the additive concentration. In sonicated experiments, however, there was significant improvement in $\mathrm{CO}_{2}$ uptake with the addition of $\mathrm{MgCl}_{2}$, increasing from 0.19 to $0.27 \mathrm{~g}, \mathrm{CO}_{2} / \mathrm{g}$,slag (60\% of the theoretical capacity) after $240 \mathrm{~min}$ with $82 \mathrm{mM} \mathrm{MgCl}$. At the same time, the preferential formation of aragonite was detected ( $86 \mathrm{wt} \%$ of the total formed carbonates). Given the acicular crystal morphology of aragonite, and its resulting low packing density when formed as a precipitated carbonate layer that surrounds the unreacted particle core, it appears that the surface erosion effect of sonication, caused by cavitation, shock waves and inter-particle collisions, becomes enhanced under these conditions. This is evidenced in the noticeable reduction in the volume moment $(\mathrm{D}[4,3])$ and surface area moment $(\mathrm{D}[3,2])$ mean particle diameters after the carbonation reaction. These observations suggest that, in the conditions tested, the carbonation enhancement effect of $\mathrm{MgCl}_{2}$ is in fact not due to calcium leaching enhancement, but rather caused by its influence on mineralogical and microstructural properties. Under other processing conditions, however, the calcium leaching enhancement of $\mathrm{MgCl}_{2}$ may be better exploited and this can be the subject of future research.

\section{Acknowledgements}

This work was supported by the KU Leuven Industrial Research Fund, through the Knowledge Platform on Sustainable Materialization of Residues from Thermal Processes into Products (SMaRT-Pro ${ }^{2}$ ), by the European Union, the Romanian Government and the Dunarea de Jos University of Galati, through the project POSDRU/107/1.5/S/76822, and by the Natural Sciences and Engineering Research 
Council of Canada (NSERC), through a PGS-D scholarship for Rafael Santos. The KU Leuven Department of Earth and Environmental Sciences and the Department of Metallurgy and Materials Engineering are acknowledged for the use of LD, TGA, XRD, $\mathrm{XRF}$ and SEM equipment.

\section{References}

Ahn, J.-W., Park, W.K., You, K.-S., Cho, H.-C., Ko, S.-J., Han, C., 2007. Roles of additives on crystal growth rate of precipitated calcium carbonate. Solid State Phenomena 124-126, 707710.

Bobicki, E.R., Liu, Q., Xu, Z., Zeng, H., 2012. Carbon capture and storage using alkaline industrial wastes. Progress in Energy and Combustion Science 38, 302-320.

Bodor, M., Santos, R.M., Van Gerven, T., Vlad, M., 2013. Recent developments and perspectives on the treatment of industrial wastes by mineral carbonation - A review. Central European Journal of Engineering, DOI:10.2478/s13531-013-0115-8.

Ceulemans, P., 2011. Improved synthesis of aragonite. M.Sc. Thesis, Katholieke Universiteit Leuven, Leuven.

Daval, D., Martinez, I., Guigner, J.-M., Hellmann, R., Corvisier, J., Findling, N., Dominici, C., Goffé, B., Guyot, F., 2009. Mechanism of wollastonite carbonation deduced from micro- to nanometer length scale observations. American Mineralogist 94, 1707-1726.

Eloneva, S., Mannisto, P., Said, A., Fogelholm, C.-J., Zevenhoven, R., 2011. Ammonium saltbased steelmaking slag carbonation: Precipitation of $\mathrm{CaCO}_{3}$ and ammonia losses assessment. Greenhouse Gases: Science and Technology 1 (4), 305-311.

Eloneva, S., Teir, S., Revitzer, H., Salminen, J., Said, A., Fogelholm, C.-J., Zevenhoven, R., 2009. Reduction of $\mathrm{CO}_{2}$ emissions from steel plants by using steelmaking slags for production of marketable calcium carbonate. Steel Research International 80 (6), 415-421.

Eloneva, S., Teir, S., Salminen, J., Fogelholm, C.-J., Zevenhoven, R., 2008. Steel converter slag as a raw material for precipitation of pure calcium carbonate. Industrial \& Engineering Chemistry Research 47, 7104-7111.

Ferrini, V., De Vito, C., Mignardi, S., 2009. Synthesis of nesquehonite by reaction of gaseous $\mathrm{CO}_{2}$ with $\mathrm{Mg}$ chloride solution: Its potential role in the sequestration of carbon dioxide. Journal of Hazardous Materials 168, 832-837.

Hu, Z.S., Shao, M.H., Li, H.Y., Cai, Q., Ding, S.G., Wei, X.P., Deng, Y.L., 2008. $\mathrm{Mg}^{2+}$ content control of aragonite whisker synthesised from calcium hydroxide and carbon dioxide in presence of magnesium chloride. Materials Science and Technology 24 (12), 1438-1443. 
Huijgen, W.J.J., Witkamp, G.-J., Comans, R.N.J., 2006. Mechanisms of aqueous wollastonite carbonation as a possible $\mathrm{CO}_{2}$ sequestration process. Chemical Engineering Science 61, $4242-4251$.

Jo, H., Jang, Y.-N., Jo, H.Y., 2012. Influence of $\mathrm{NaCl}$ on mineral carbonation of $\mathrm{CO}_{2}$ using cement material in aqueous solutions. Chemical Engineering Science 80, 232-241.

Kim, J.-H., Ahn, J.-W., Ko, S.-J., Park, W.-K., Han, C., 2006. Inhibition mechanism of magnesium ion on carbonation reaction with $\mathrm{Ca}(\mathrm{OH})_{2}$ and $\mathrm{CO}_{2}$. Materials Science Forum 510-511, 990-993.

Kirchofer, A., Becker, A., Brandt, A., Wilcox, J., 2013. $\mathrm{CO}_{2}$ mitigation potential of mineral carbonation with industrial alkalinity sources in the United States. Environmental Science \& Technology, 47, 7548-7554.

Kitano, Y., Hood, D.W., 1962. Calcium carbonate crystal forms formed from sea water by inorganic processes. The Journal of the Oceanographic Society of Japan 18 (3), 141-145.

Kitano, Y., Tokuyama, A., Arakaki, T., 1979. Magnesian calcite synthesis from calcium 726 bicarbonate solution containing magnesium and barium ions. Geochemical Journal 13, 181185.

Kurdowski, W., 2004. The protective layer and decalcification of C-S-H in the mechanism of chloride corrosion of cement paste. Cement and Concrete Research 34, 1555-1559.

Kurdowski, W., Duszak, S., 1995. Changes of C-S-H gel in strong chloride solution. Advances in Cement Research 7 (28), 143-149.

Ma, J., Liu, H.-Y., Chen, Y.-F., 2011. Reuse of $\mathrm{MgCl}_{2}$ as crystal controlling agent in the synthesis process of needle-like calcium carbonate. Journal of Inorganic Materials 26 (11), 1199-1204.

Mignardi, S., De Vito, C., Ferrini, V., Martin, R.F., 2011. The efficiency of $\mathrm{CO}_{2}$ sequestration via carbonate mineralization with simulated wastewaters of high salinity. Journal of Hazardous Materials 191, 49-55.

Pan, S.-Y., Chang, E.E., Chiang, P.-C., 2012. $\mathrm{CO}_{2}$ capture by accelerated carbonation of alkaline wastes: a review on its principles and applications. Aerosol and Air Quality Research 12, 770-791.

Passe-Coutrin, N., N'Guyen, Ph., Pelmard, R., Ouensanga, A., Bouchon, C., 1995. Water desorption and aragonite-calcite phase transition in scleractinian corals skeletons. Thermochimica Acta 265, 135-140.

Prozorov, T., Prozorov, R., Suslick, K.S., 2004. High velocity interparticle collisions driven by ultrasound. Journal of the American Chemical Society 126 (43), 13890-13891. 
Sanna, A., Hall, M.R., Maroto-Valer, M, 2012. Post-processing pathways in carbon capture and storage by mineral carbonation (CCSM) towards the introduction of carbon neutral materials. Energy \& Environmental Science 5, 7781-7796.

Santos, R.M., Ceulemans, P., Van Gerven, T., 2012. Synthesis of pure aragonite by sonochemical mineral carbonation. Chemical Engineering Research and Design 90 (6), 715 725 .

Santos, R.M., François, D., Mertens, G., Elsen, J., Van Gerven, T., 2013a. Ultrasoundintensified mineral carbonation. Applied Thermal Engineering 57(1-2), 154-163.

Santos, R.M., Van Bouwel, J., Vandevelde, E., Mertens, G., Elsen, J., Van Gerven, T. 2013b. Accelerated mineral carbonation of stainless steel slags for $\mathrm{CO}_{2}$ storage and waste valorization: effect of process parameters on geochemical properties. International Journal of Greenhouse Gas Control 17, 32-45.

Santos, R.M., Van Gerven, T., 2011. Process intensification routes for mineral carbonation. Greenhouse Gases: Science and Technology, 1(4), 287-293.

Shu, D., Sun, B., Mi, J., Grant, P.S., 2012. A high-speed imaging and modeling study of dendrite fragmentation caused by ultrasonic cavitation. Metallurgical and Materials Transactions A 43(10), 3755-3766.

Sinadinović, D., Kamberović, Ž., Šutić, A., 1997. Leaching kinetics of lead from lead (II) sulphate in aqueous calcium chloride and magnesium chloride solutions. Hydrometallurgy 47, 137-147.

Xiang, L., Wen, Y., Wang, Q., Jin, Y., 2006. Synthesis of dispersive $\mathrm{CaCO}_{3}$ in the presence of $\mathrm{MgCl}_{2}$. Materials Chemistry and Physics 98, 236-240.

Yasunishi, A., Yoshida, F., 1979. Solubility of carbon dioxide in aqueous electrolyte solutions. Journal of Chemical and Engineering Data 24 (1), 11-14.

Zevenhoven, R., Fagerlund, J., Songok, J.K., 2011. $\mathrm{CO}_{2}$ mineral sequestration: developments toward large-scale application. Greenhouse Gases: Science and Technology 1 (1) 48-57. 


\section{List of Figures:}

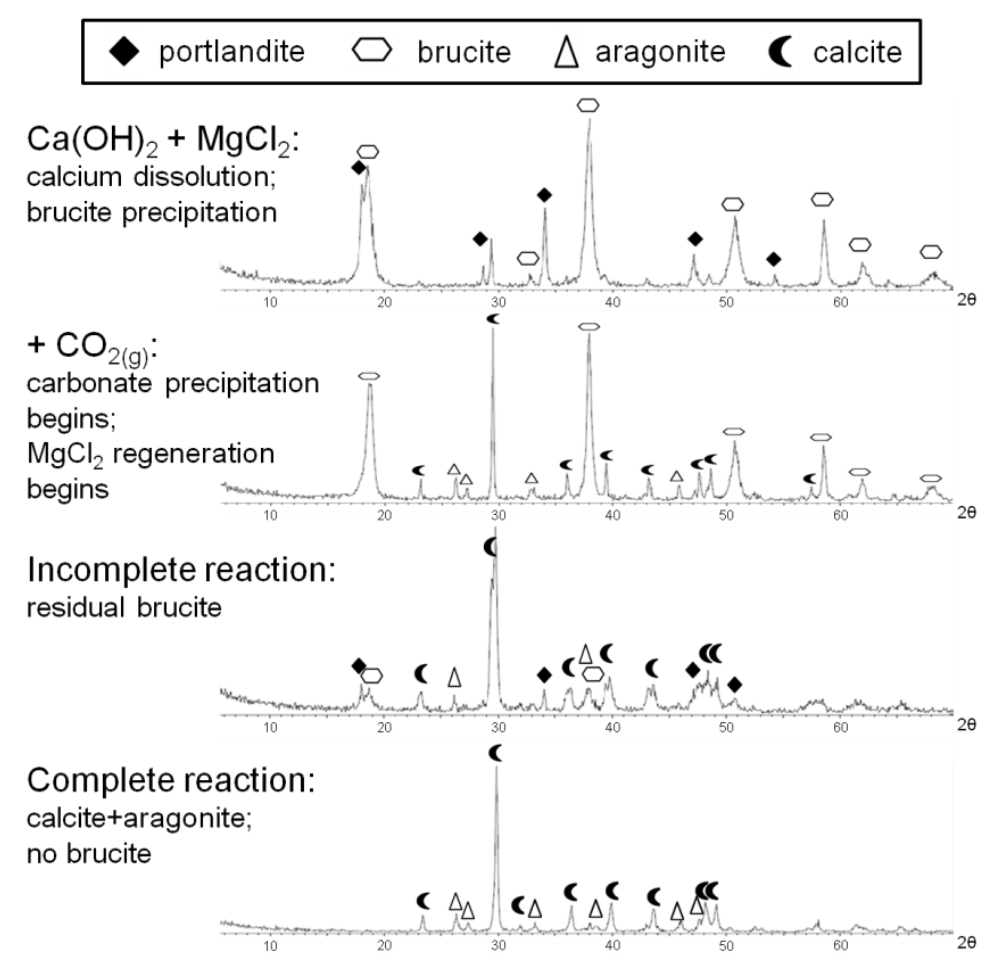

Fig. 1. Self-regenerative cycle of $\mathrm{MgCl}_{2}$ as applied during carbonation of $\mathrm{Ca}(\mathrm{OH})_{2}$; adapted from Ceulemans (2011). 

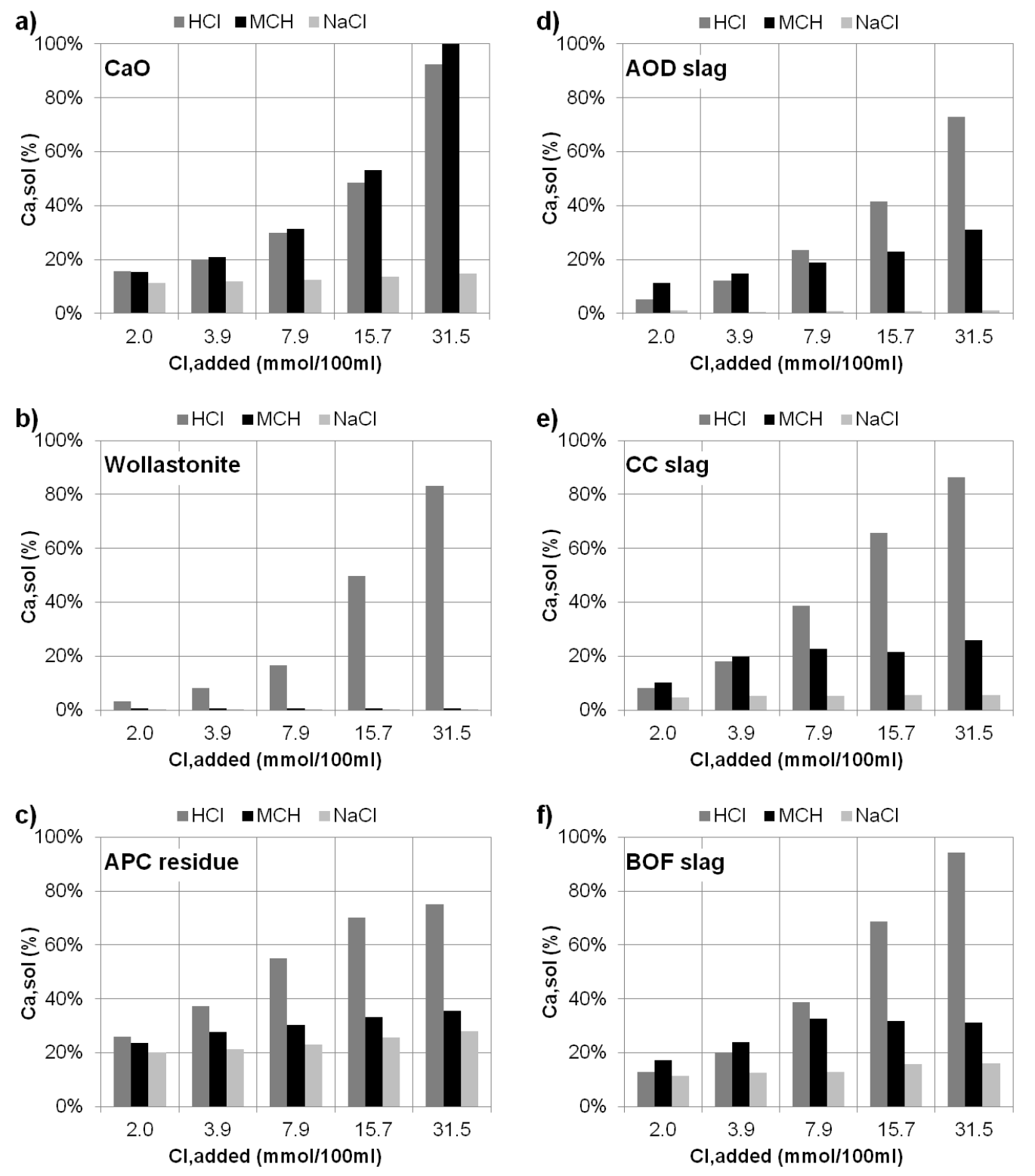

Fig. 2. Extent of calcium leaching from $\mathrm{CaO}$ (a), wollastonite (b) APC residue (c), AOD slag (d), $\mathrm{CC}$ slag (e) and BOF slag (f) as a function of $\mathrm{HCl}, \mathrm{MgCl}_{2} \cdot 6 \mathrm{H}_{2} \mathrm{O}(\mathrm{MCH})$ and $\mathrm{NaCl}$ additions, expressed on the basis of moles of added chloride; $1 \mathrm{~g} / 100 \mathrm{ml}$ solids used. 

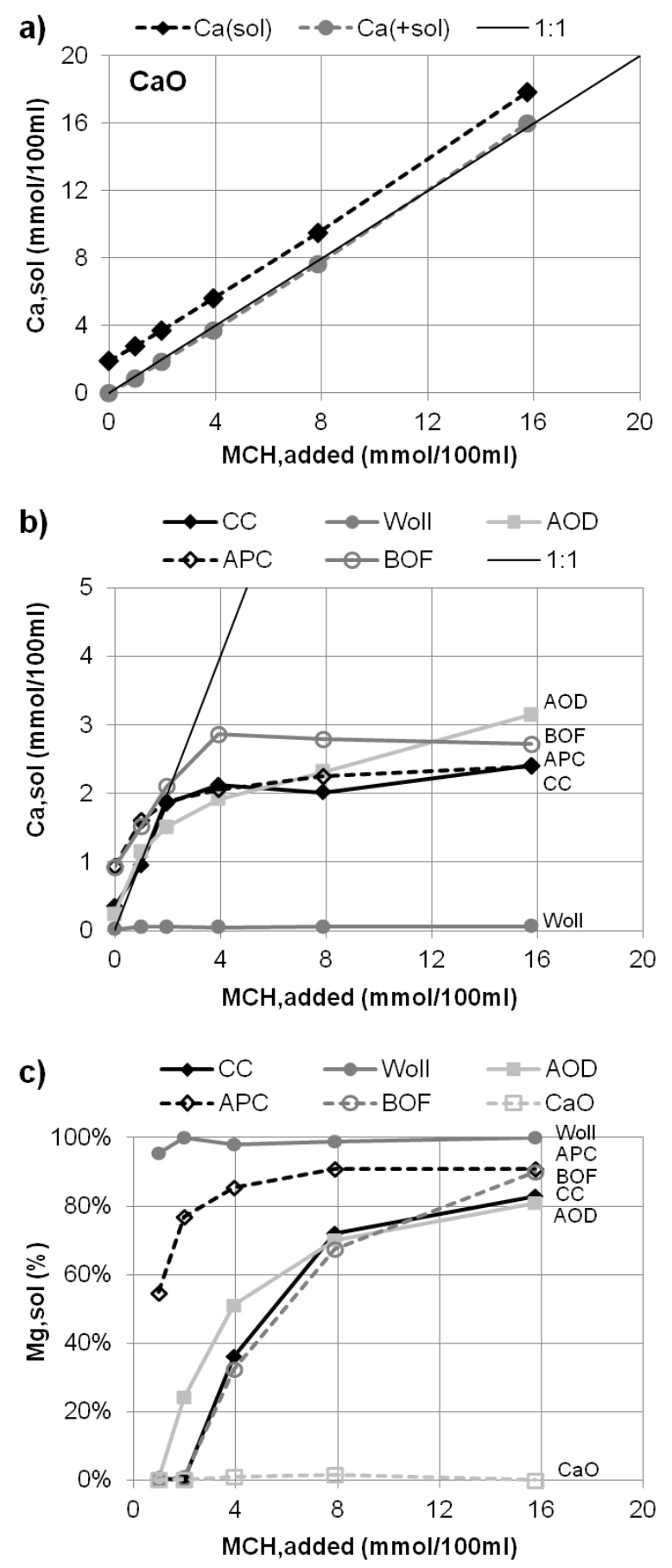

Fig. 3. Calcium solubility from $\mathrm{CaO}$ (a) and other alkaline materials (b) as a function of amount of $\mathrm{MCH}$ added; and fraction of added $\mathrm{Mg}$ remaining in solution as a function of amount of $\mathrm{MCH}$ added to each alkaline material solution (c). 


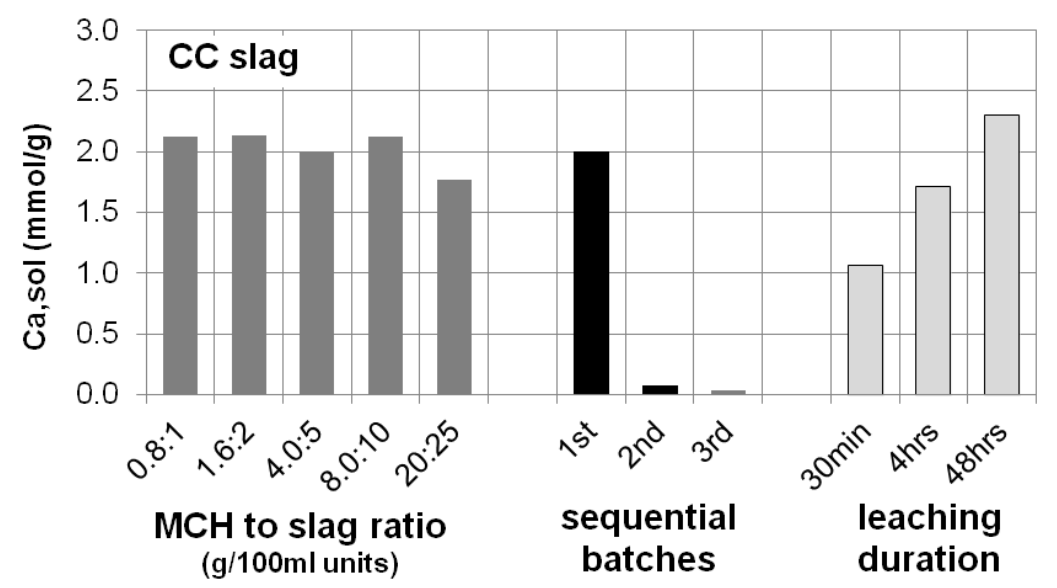

Fig. 4. Calcium solubilisation from CC slag as a function of: increasing solids concentration at fixed MCH to slag ratio (g/100ml units) and 24 hours duration; sequential leaching for 24 hours each batch with $\mathrm{MCH}$ to slag ratio of 4.0:5, and; leaching duration with $\mathrm{MCH}$ to slag ratio of $0.8: 1$. 

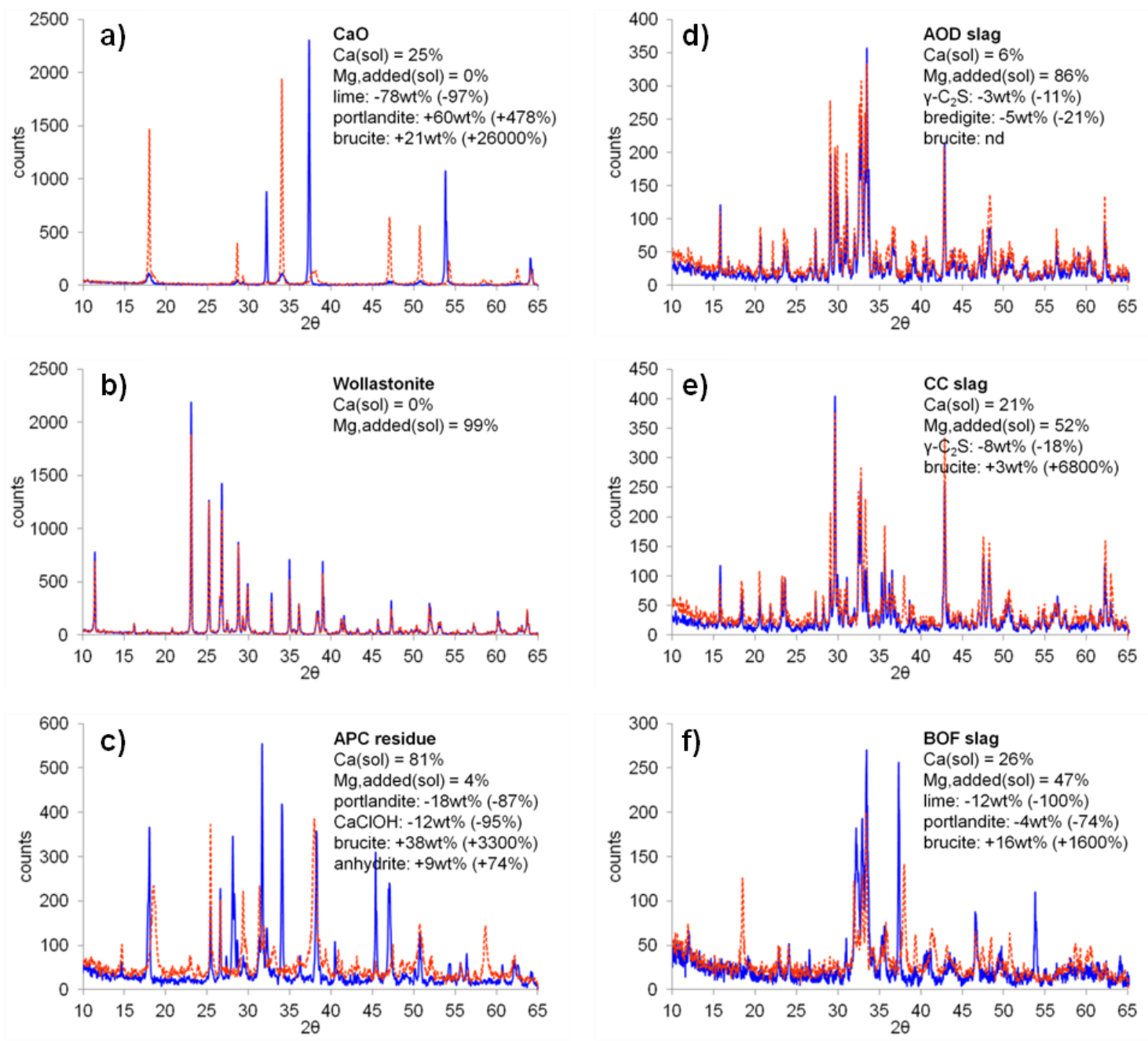

Fig. 5. Change of mineralogical composition of alkaline materials after leaching with $\mathrm{MCH}$ for 24 hours using $\mathrm{MCH}$ to solids ratio of 4.0:5, determined by QXRD; blue solid lines represent original materials, and red dashed lines are leached materials (colour in electronic version); $\mathrm{Ca}$ (sol) is percentage fraction of calcium dissolved from solids; $\mathrm{Mg}$,added(sol) is percentage fraction of added magnesium that remained in solution; changes in mineral composition of main dissolved, precipitated or enriched phases is shown (in wt $\%$ change and $\%$ change compared to original composition). 


\section{a) Mixer}

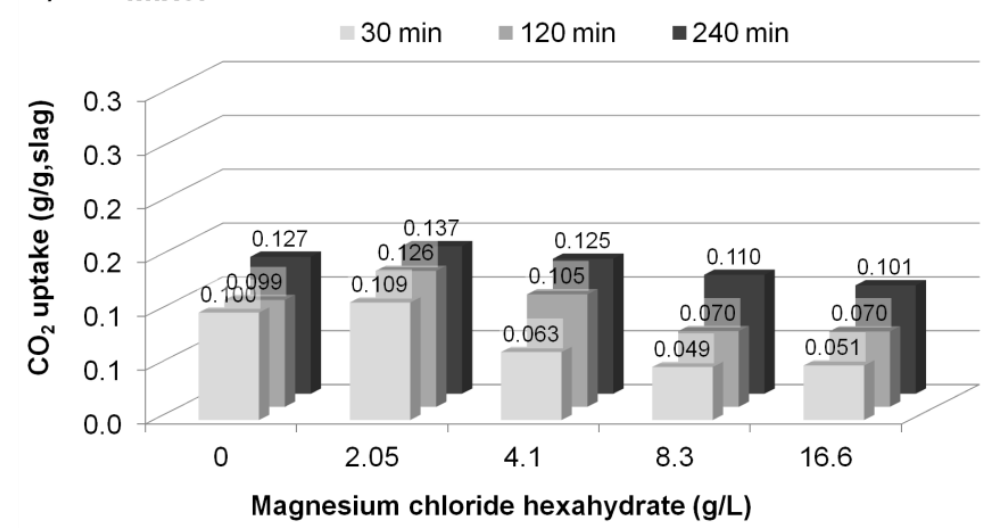

b) Mixer + US

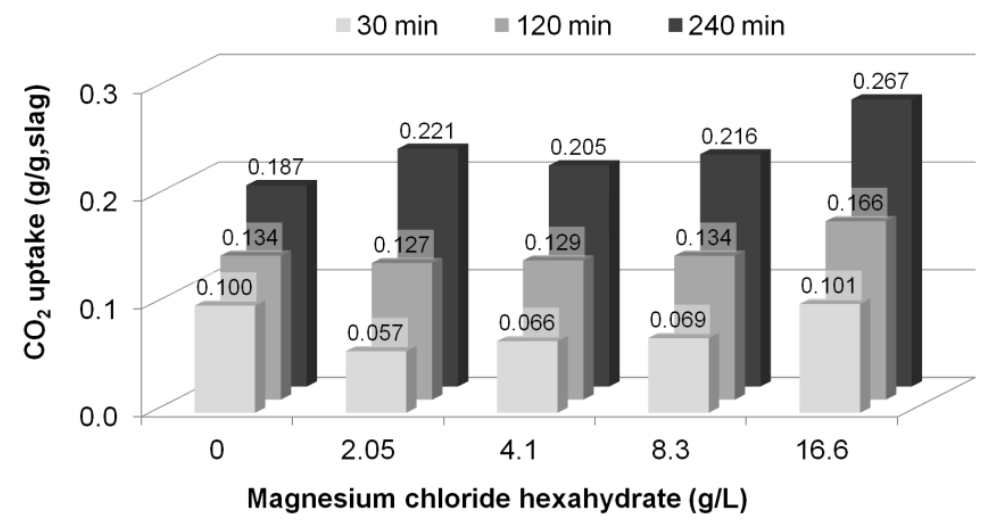

Fig. 6. $\mathrm{CO}_{2}$ uptake of carbonated AOD slag using mixer-only (a) and combination mixer/ultrasound (b) as a function of amount of $\mathrm{MCH}$ added and reaction time. 

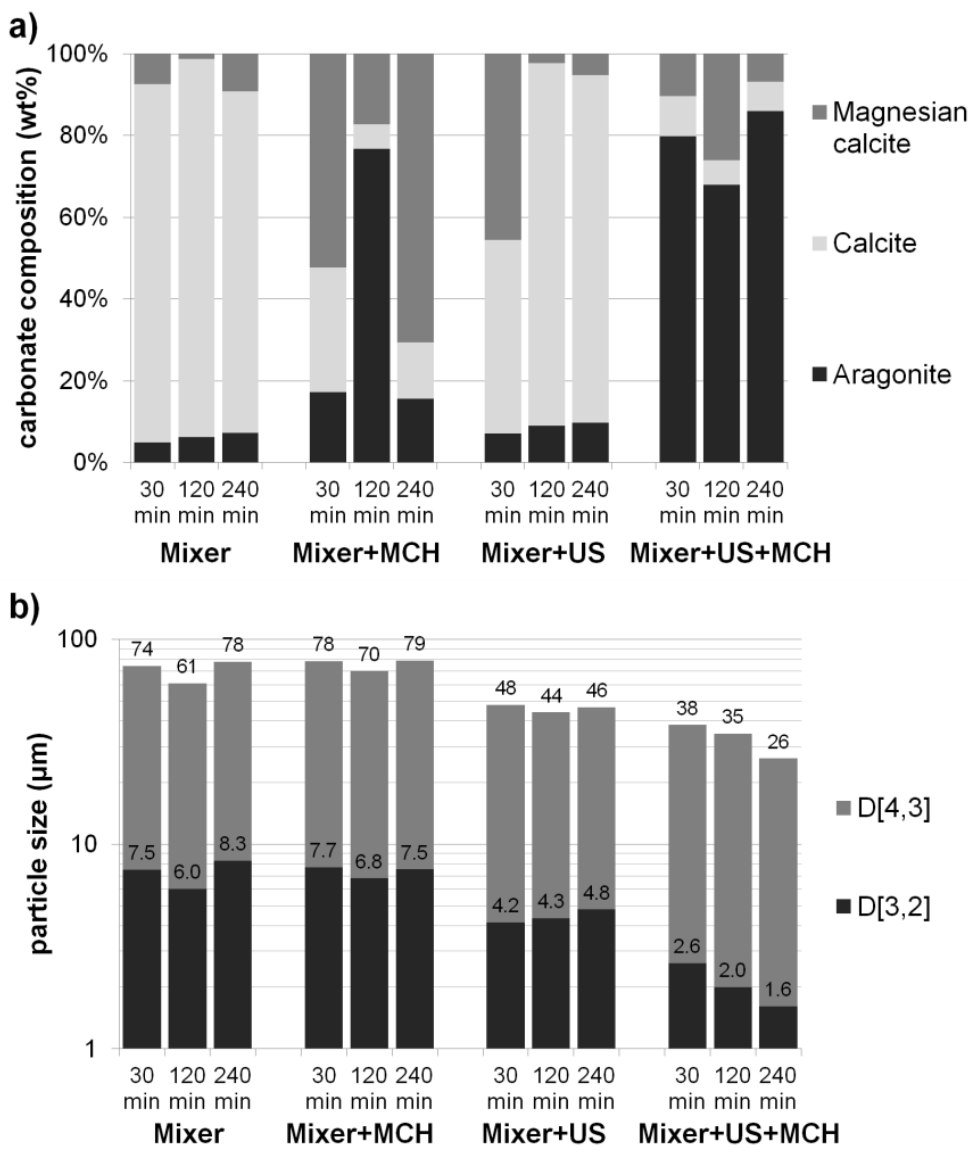

Fig. 7. Carbonate composition (a) and mean particle diameters (b) of carbonated AOD slag using mixer-only, combination mixer/ultrasound, with and without $\mathrm{MCH}$ addition, as a function of reaction time; results with varying $\mathrm{MCH}$ dosages were averaged to facilitate plotting. 


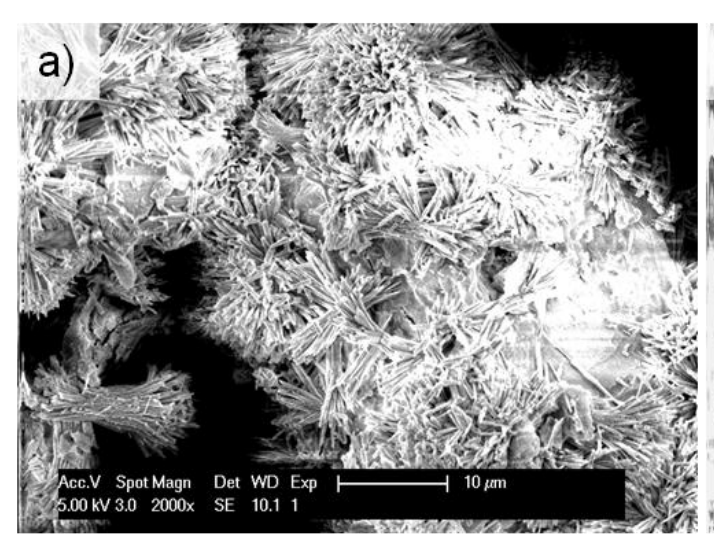

Mixer + $2.05 \mathrm{~g} / \mathrm{L} \mathrm{MCH}, 120 \mathrm{~min}$

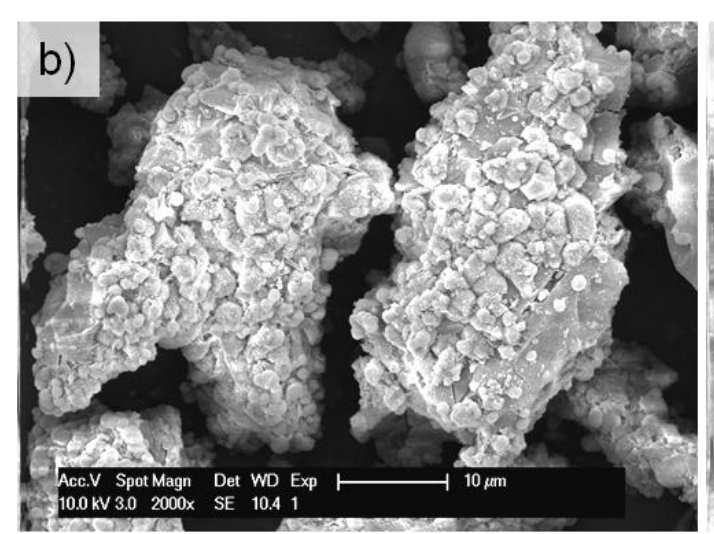

Mixer + $2.05 \mathrm{~g} / \mathrm{L} \mathrm{MCH}, 240 \mathrm{~min}$

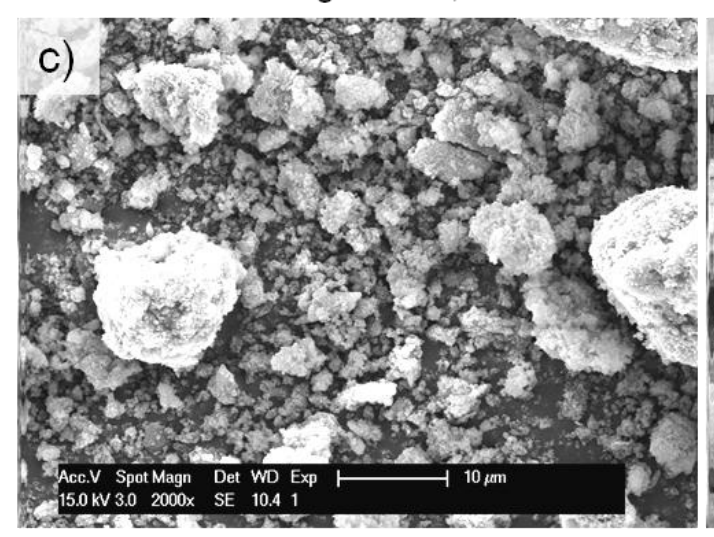

Mixer + US + $2.05 \mathrm{~g} / \mathrm{L} \mathrm{MCH}, 240 \mathrm{~min}$

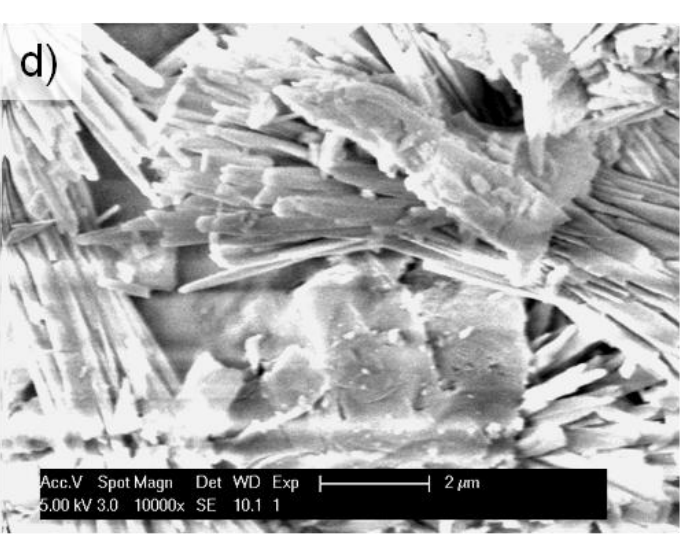

Mixer + $2.05 \mathrm{~g} / \mathrm{L} \mathrm{MCH}, 120 \mathrm{~min}$
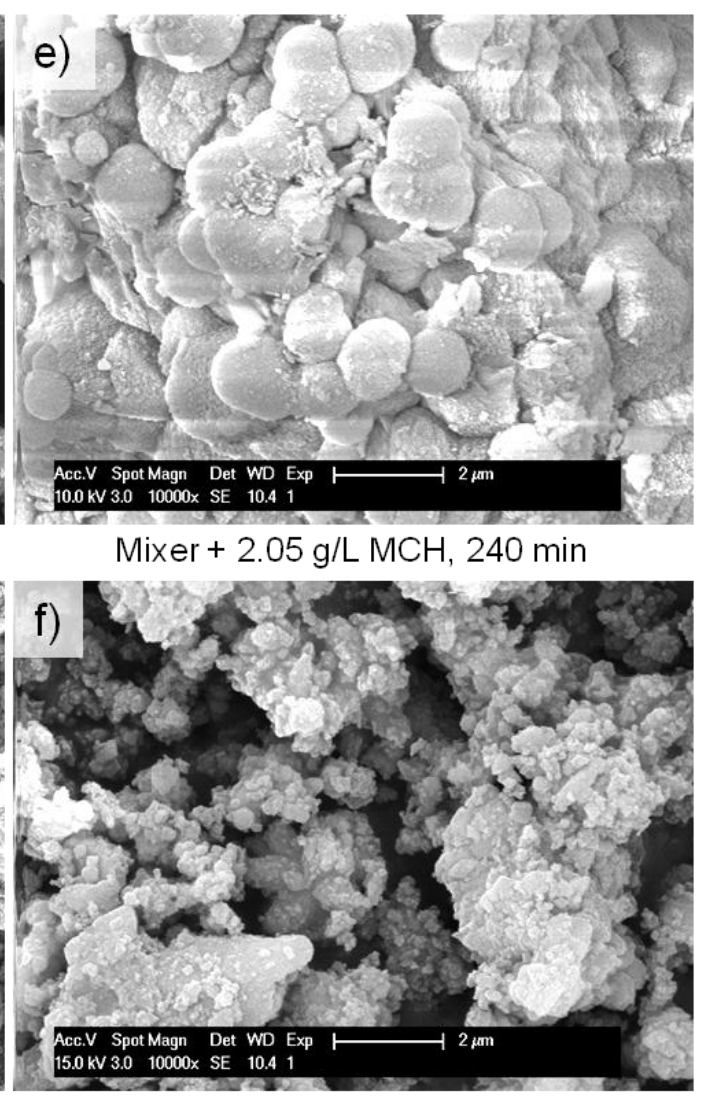

Mixer + US + $2.05 \mathrm{~g} / \mathrm{L} \mathrm{MCH}, 240 \mathrm{~min}$

Fig. 8. Morphology of carbonated AOD slag particles using mixer-only with MCH after 120 $(\mathrm{a}, \mathrm{d})$ and 240 (b,e) minutes reaction time, and using combination mixer/ultrasound with $\mathrm{MCH}$ after 240 minutes reaction time (c,f). 


\section{List of Tables:}

Table 1

Chemical composition (expressed as wt $\%$ oxides) of alkaline materials (in order of $\mathrm{CaO}$ content) determined by XRF (normalized to $100 \mathrm{wt} \%$ total; $\geq 1.0 \mathrm{wt} \%$ shown).

\begin{tabular}{llllllllllll}
\hline & $\mathrm{Al}_{2} \mathrm{O}_{3}$ & $\mathrm{CaO}$ & $\mathrm{Cl}$ & $\mathrm{Fe}_{2} \mathrm{O}_{3}$ & $\mathrm{~K}_{2} \mathrm{O}$ & $\mathrm{MgO}$ & $\mathrm{MnO}$ & $\mathrm{Na}_{2} \mathrm{O}$ & $\mathrm{SO}_{3}$ & $\mathrm{SiO}_{2}$ & $\mathrm{TiO}_{2}$ \\
\hline $\mathrm{CaO}$ & $<$ & 98.3 & $<$ & $<$ & $<$ & 1.1 & $<$ & $<$ & $<$ & $<$ & $<$ \\
AOD slag & 1.0 & 56.8 & $<$ & $<$ & $<$ & 7.5 & $<$ & $<$ & $<$ & 32.5 & $<$ \\
CC slag & 1.1 & 52.0 & $<$ & 1.3 & $<$ & 9.9 & $<$ & $<$ & $<$ & 27.5 & $<$ \\
Wollastonite & $<$ & 51.2 & $<$ & $<$ & $<$ & $<$ & $<$ & $<$ & $<$ & 46.4 & $<$ \\
APC residue & 1.5 & 49.8 & 22.2 & $<$ & 2.7 & $<$ & $<$ & 10.9 & 6.4 & 2.9 & 1.1 \\
BOF slag & 2.5 & 49.0 & $<$ & 29.5 & $<$ & 1.0 & 3.6 & $<$ & $<$ & 12.4 & $<$ \\
\hline
\end{tabular}

$<$ : less than $1.0 \mathrm{wt} \%$. 


\section{Table 2}

Mineral composition of alkaline materials determined by QXRD (wt\% of crystalline total).

\begin{tabular}{|c|c|c|c|c|c|c|c|}
\hline Mineral name & $\begin{array}{l}\text { Chemical } \\
\text { formula }\end{array}$ & $\mathrm{CaO}$ & Wollastonite & $\begin{array}{l}\text { AOD } \\
\text { slag }\end{array}$ & $\begin{array}{l}\mathrm{CC} \\
\text { slag }\end{array}$ & $\begin{array}{l}\text { BOF } \\
\text { slag }\end{array}$ & $\begin{array}{l}\text { APC } \\
\text { residue }\end{array}$ \\
\hline Åkermanite & $\mathrm{Ca}_{2} \mathrm{MgSi}_{2} \mathrm{O}_{7}$ & nd & nd & 1.2 & 1.7 & nd & nd \\
\hline Anhydrite & $\mathrm{CaSO}_{4}$ & nd & nd & nd & nd & nd & 12.5 \\
\hline Bredigite & $\mathrm{Ca}_{7} \mathrm{Mg}\left(\mathrm{SiO}_{4}\right)_{4}$ & nd & nd & 24.1 & 6.7 & nd & nd \\
\hline Brucite & $\mathrm{Mg}(\mathrm{OH})_{2}$ & nd & nd & 0.2 & 0.0 & 1.0 & 1.1 \\
\hline Calcium chloride hydroxide & $\mathrm{Ca}(\mathrm{OH}) \mathrm{Cl}$ & nd & nd & nd & nd & nd & 12.3 \\
\hline Chlorapatite & $\mathrm{Ca}_{5}\left(\mathrm{PO}_{4}\right)_{3} \mathrm{Cl}$ & nd & nd & nd & nd & nd & 15.7 \\
\hline Clinoenstatite & $\mathrm{Mg}_{2} \mathrm{Si}_{2} \mathrm{O}_{6}$ & nd & nd & 1.9 & 10.7 & 4.9 & nd \\
\hline Cuspidine & $\mathrm{Ca}_{4} \mathrm{Si}_{2} \mathrm{O}_{7} \mathrm{~F}_{2}$ & nd & nd & 13.5 & 6.4 & nd & nd \\
\hline$\beta$-Dicalcium silicate & $\mathrm{Ca}_{2} \mathrm{SiO}_{4}$ & nd & nd & 7.7 & 7.1 & 19.4 & nd \\
\hline$\gamma$-Dicalcium silicate & $\mathrm{Ca}_{2} \mathrm{SiO}_{4}$ & nd & nd & 28.9 & 43.8 & 3.5 & nd \\
\hline Fayalite & $\mathrm{Fe}_{2} \mathrm{SiO}_{4}$ & nd & nd & 0.2 & 0.7 & 0.7 & nd \\
\hline Ferrosilite & $\left(\mathrm{Fe}^{(\mathrm{II})}, \mathrm{Mg}\right)_{2} \mathrm{Si}_{2} \mathrm{O}_{6}$ & nd & nd & nd & nd & 1.0 & nd \\
\hline Gehlenite & $\mathrm{Ca}_{2} \mathrm{Al}_{2} \mathrm{SiO}_{7}$ & nd & nd & 1.0 & 0.1 & nd & nd \\
\hline Halite & $\mathrm{NaCl}$ & nd & nd & nd & nd & nd & 23.4 \\
\hline Hematite & $\mathrm{Fe}_{2} \mathrm{O}_{3}$ & nd & nd & nd & nd & 8.8 & nd \\
\hline Hydromolysite & $\mathrm{FeCl}_{3} \cdot 6\left(\mathrm{H}_{2} \mathrm{O}\right)$ & nd & nd & nd & nd & nd & 2.4 \\
\hline Iron & $\mathrm{Fe}$ & nd & nd & nd & nd & 0.4 & nd \\
\hline Lime & $\mathrm{CaO}$ & 86.4 & nd & 0.4 & 0.4 & 12.3 & 2.2 \\
\hline Magnetite & $\mathrm{Fe}_{3} \mathrm{O}_{4}$ & nd & nd & 0.7 & 1.0 & 1.0 & nd \\
\hline Merwinite & $\mathrm{Ca}_{3} \mathrm{Mg}\left(\mathrm{SiO}_{4}\right)_{2}$ & nd & nd & 11.1 & 6.1 & nd & nd \\
\hline Periclase & $\mathrm{MgO}$ & nd & nd & 5.6 & 12.4 & 0.8 & 0.2 \\
\hline Portlandite & $\mathrm{Ca}(\mathrm{OH})_{2}$ & 13.6 & nd & 0.4 & 1.0 & 5.6 & 20.5 \\
\hline Quartz & $\mathrm{SiO}_{2}$ & nd & 9.3 & 0.9 & 0.4 & 1.2 & 0.0 \\
\hline Srebrodolskite & $\mathrm{Ca}_{2} \mathrm{Fe}_{2} \mathrm{O}_{5}$ & nd & nd & nd & nd & 37.8 & nd \\
\hline Sylvine & $\mathrm{KCl}$ & nd & nd & nd & nd & nd & 6.4 \\
\hline Tachyhydrite & $\mathrm{CaMg}_{2} \mathrm{Cl}_{6} \cdot 12 \mathrm{H}_{2} \mathrm{O}$ & nd & nd & nd & nd & nd & 3.4 \\
\hline Wollastonite & $\mathrm{CaSiO}_{3}$ & nd & 90.7 & 2.4 & 1.6 & nd & nd \\
\hline Wüstite & $\mathrm{FeO}$ & nd & nd & nd & nd & 1.6 & nd \\
\hline Total crystalline & & 100 & 100 & 100 & 100 & 100 & 100 \\
\hline
\end{tabular}

nd: not detected. 
Table 3

Geochemical modeling (Visual MINTEQ) results of the effect of $\mathrm{MCH}$ addition (81.65 mM) and calcite saturation on the $\mathrm{CO}_{2}$ solubility and $\mathrm{H}_{2} \mathrm{CO}_{3}$ dissociation; $\mathrm{P}\left(\mathrm{CO}_{2}\right)=1 \mathrm{~atm}, \mathrm{~T}=50^{\circ} \mathrm{C}$.

\begin{tabular}{|c|c|c|c|c|}
\hline Log activity (M) & $\begin{array}{l}0 \mathrm{mM} \mathrm{MCH} \mathrm{+} \\
\text { pure water }\end{array}$ & $\begin{array}{c}81.65 \mathrm{mM} \mathrm{MCH} \mathrm{+} \\
\text { pure water }\end{array}$ & $\begin{array}{c}0 \mathrm{mM} \mathrm{MCH} \mathrm{+} \\
\text { calcite-saturated }\end{array}$ & $\begin{array}{c}81.65 \mathrm{mM} \mathrm{MCH} \mathrm{+} \\
\text { calcite-saturated }\end{array}$ \\
\hline $\mathrm{Ca}^{+2}$ & - & - & -2.496 & -2.619 \\
\hline $\mathrm{CaCl}^{+}$ & - & - & - & -3.127 \\
\hline $\mathrm{CaCO}_{3(\mathrm{aq})}$ & - & - & -5.166 & -5.166 \\
\hline $\mathrm{CaHCO}_{3}^{+}$ & - & - & -3.288 & -3.349 \\
\hline $\mathrm{CaOH}^{+}$ & - & - & -8.322 & -8.383 \\
\hline $\mathrm{Cl}^{-}$ & - & -0.959 & - & -0.962 \\
\hline $\mathrm{CO}_{3}^{-2}$ & -10.175 & -10.268 & -6.167 & -6.044 \\
\hline $\mathrm{H}^{+}$ & -3.998 & -3.952 & -6.002 & -6.064 \\
\hline $\mathrm{H}_{2} \mathrm{CO}_{3(\mathrm{aq})}$ & -1.711 & -1.711 & -1.711 & -1.711 \\
\hline $\mathrm{HCO}_{3}^{-}$ & -3.998 & -4.045 & -1.995 & -1.933 \\
\hline $\mathrm{Mg}^{+2}$ & - & -1.706 & - & -1.733 \\
\hline $\mathrm{Mg}_{2} \mathrm{CO}_{3}^{+2}$ & - & -10.091 & - & -5.919 \\
\hline $\mathrm{MgCl}^{+}$ & - & -2.011 & - & -2.04 \\
\hline $\mathrm{MgCO}_{3(\mathrm{aq})}$ & - & -8.888 & - & -4.69 \\
\hline $\mathrm{MgHCO}_{3}^{+}$ & - & -4.664 & - & -2.578 \\
\hline $\mathrm{MgOH}^{+}$ & - & -8.287 & - & -6.201 \\
\hline $\mathrm{OH}^{-}$ & -9.242 & -9.289 & -7.238 & -7.177 \\
\hline Total $\mathrm{CO}_{2(\mathrm{aq})}$ & -1.709 & -1.708 & -1.521 & -1.465 \\
\hline \multicolumn{5}{|l|}{ Concentration $(\mathrm{M})$} \\
\hline Total $\mathrm{CO}_{2(\mathrm{aq})}$ & 0.0196 & 0.0187 & 0.0316 & 0.0387 \\
\hline
\end{tabular}

